\title{
Foreign Aid and Its Impact on Democracy in Post-1991 Ethiopia
}

\author{
Habtie Adane \\ Debre Berhan University, Debre Berhan, Ethiopia \\ Email: habt2002@gmail.com
}

Received 1 May 2015; accepted 17 May 2015; published 26 May 2015

Copyright (C) 2015 by author and OALib.

This work is licensed under the Creative Commons Attribution International License (CC BY). http://creativecommons.org/licenses/by/4.0/

C)

\section{Abstract}

Ethiopia is an aid-dependent Horn of African country that is known to have received various forms of assistance, especially the humanitarian one. With the Cold War getting over, the country started receiving democracy assistance being pledged to realize democratic ideals. This article is concerned with foreign aid and its impact on democracy in Ethiopia in the post-1991 period. Its overall objective is thus to explore issues pertaining to the impact of foreign aid on Ethiopia's democratization drive in the stated period. To substantiate my explanations and analyses, both primary and secondary data are used once generated through key informant interviews and document analysis. In this article I argue that issues of ideology, sovereignty, national interest, and geopolitics have significantly challenged democracy assistance in Ethiopia in the post-1991 period. I also contend that weak rules and laws, corruption, and weak mechanisms that govern relations between the Ethiopian government and donors have had a negative impact on foreign aid in the country. The study concludes that the contribution of foreign aid in fostering democracy in Ethiopia in the post-1991 period has been negligible in spite of the fact that an institutionalized form of democracy assistance, which is currently provided by the Democratic Institutions Program (DIP) to some governmentally established institutions, underscores the evolving face of democracy assistance in Ethiopia, albeit it is criticized by some for favoring governmental institutions at the expense of non-governmental organizations.

\section{Keywords}

Democracy, Democracy Assistance, Donors, Ethiopia, Foreign Aid

Subject Areas: International Relations

\section{Introduction}

As discussed by Thorp [1], the flow of foreign aid to developing countries has a long-standing history taking 
place largely through private ventures, missionary activities, and migration. However, many researchers agreed that foreign aid as an institution began in the late 1940s, especially with the 1947 Marshall Plan, which aimed at the reconstruction of European economies devastated by World War II. And almost immediately, attention was paid to the impact of large amounts of aid on the behavior and attitudes of recipient governments.

Ethiopia has been one of the major recipients of foreign aid in recent times. However, the history of foreign aid in the country dates, just as in most of African countries, as far back to the immediate post-World War II period. According to Jifar [2], the inflow of external loans and grants to Ethiopia started in the early 1950s. During the three consecutive Five-Year Plan periods (1957-1973), 25 per cent of the total required investment was covered by official aid (ibid). It is often argued that the direction of foreign aid is characterized by negligible longrun objectives as it is subject to infrastructural development compared to direct investment activities on agricultural and industrial sectors. Likewise, during the post-revolution period, i.e. after 1974, 37 per cent of the total annual budget of 1979-1983 was financed by foreign aid (Tolessa, 2001, in Jifar, 2002: 3). However, following the end of the Cold War and the political transformations in the country as a result of the downfall of the military regime by the Ethiopian Peoples' Revolutionary Democratic Front (EPRDF), the concern for foreign aid to Ethiopia has been revitalized. For this reason, the flow of aid to the country has been increasing steadily in the post-1991 period. This study investigates the role of foreign aid in democratization process in the country in the post-1991 period.

\section{The Aid Regime and Its Effect on Democratization in Post-1991 Ethiopia}

\subsection{Theories of Foreign Aid}

In this section, it is tried to highlight the most outstanding foreign aid theories that are used by different aid practitioners to provide theoretical picture and rationales for development assistance. These theories are essentially founded on some basic paradigms concerned with relations among states. Accordingly, these scholars [3][7] attempt to understand external assistance in light of international relations (IR) theories: realist paradigm (foreign aid as an instrument of enhancing national power and security of the donor country, for example, through reducing the temptations and threats of communism or terrorism); idealist paradigm (foreign aid as a humanitarian motive and as a source of co-operation between donors and recipients); Marxist paradigm (foreign aid as a means of advancing capitalist exploitation and widening economic disparities between wealthy industrial nations and poor Third-World countries, now designated as developing countries); and constructivist paradigm (foreign aid as a reflection of morality). The overall role and relevance in the aid regime of each one of these theories is explained (having reference to the assumptions and conceptions of the above scholars) a little bit in detail as follows.

Interpreted through the realist lens, aid programs of donor countries are assumed to be driven by donors' national-interest motivations, which are both political and economic (Lancaster, 2007: 3; Carbone, 2007: 40). The basic reason for this is that because states fear and suspect each other in an international system, which is full of anarchy and danger, they want to maximize their power, security, and well-being (as was evident during the Cold War era in which donor countries and agencies that belonged to either of the two super powers supported poor Third-World countries on the basis of the latter's allegiance in the bi-polar world). However, with the end of the Cold War super-power political confrontations between the U.S. and the former Soviet Union, "the political rationale for aid lost its meaning and most donors cut their aid budgets" (ibid). Security as a motivation for external assistance programs re-emerged with greater energy and intensity following the Pentagon attacks by terrorists as of September 2001 (ibid). The two variants of realism school of thought: classical-realism and neo-realism-which have different conceptions of what security, power, and international system entails (Cosgriff, 2001: 7)—are often used to view the rationales behind the aid regime. Accordingly, classical realists argue that donors design and implement aid programs thereby initially considering the political, military, and strategic importance of recipient states (ibid). Whereas, neo-realists consider the economic dimension of national security, with the recipient country's economic potential providing momentum for aid priorities (ibid). Therefore, seen in this light, the donor community could have used external assistance as an instrument to help them survive and/or maximize their power in an anarchic world.

Idealists (or liberal internationalists), who argue that human behavior is inherently good, posit that aid programs are shaped by optimistic and non-material motivations and desires, such as altruism and moral and/or 
humanitarian obligations (ibid: 41). In this regard, foreign aid is viewed as "an instrument or [a] reflection of the tendency of states to cooperate in addressing problems of interdependence and globalization" (Lancaster, 2007: 4). Therefore, on the back of these moral and/or humanitarian motives, an ever increasing amount of aid is believed to have been channeled mainly from the West to the rest through international institutions (notably the IMF, the WB and DAC) with the overriding goal of solving the world's daunting challenges, like infectious diseases, environmental degradation, poverty, hunger, and the like.

Marxist-Leninist assumptions and arguments about the role of economic wealth in enhancing the political power of elites in industrialized as well as in Least Developed Countries (LDCs) underlie the third major theoretical perspective applied to the analysis and critique of foreign aid programs (Van Belle et al., 2004: 13). Accordingly, economic and commercial motives are central to aid donor motives (Cosgriff, 2001: 8). Thus, development assistance is provided based on the premise that capitalist exploitation enhances the power and prestige of developed and industrialized countries at the very cost of developing ones, i.e. while the West flourishes, the rest impoverishes (ibid). Therefore, Marxism carries with it the core argument that foreign aid functions to help deepen and widen the existing economic disparities between wealthy donor states and poor recipient states.

Foreign aid is also viewed and judged in terms of constructivist thinking. Constructivists, who "often point to the increased legitimacy and enhanced enforcement mechanisms of international law, as well as government's attempts to pay at least rhetorical attention to human rights” (Barratt, 2008: 14), argue that aid programs of donor countries and agencies are designed and implemented not for the sake of maximizing power and security of donor countries or not for necessarily enhancing co-operations between donors and recipients, but for the sake of moral imperatives (i.e., aid as an expression of the norm in which powerful and rich countries provide assistances to poor countries to help the latter better the living standards and the quality of lives of their peoples (Lancaster, 2007: 4)). Thus, humanitarian considerations in the donor countries are assumed to be the main rationales behind supporting the developing world.

According to Lancaster (ibid), "none of these theories of international relations explain[s] adequately the complexities of aid's [goals] [a]nd all of them together lack one important element: the impact of domestic politics on aid-giving". However, it is important to note that some kind of alchemies exist among these theories when seen in terms of their relevance to donors and recipients. So, it seems to me reasonable to believe that realist and Marxist theories appear to be donor-oriented and satisfy their motives while the idealist and constructivist thinking seem to be recipient-oriented and intended to serve their aspirations.

Of all these theories, realism appears to me much more influential in explaining and conditioning the aid regime in the today's world. Because, donors (with their foreign policy objectives dictating their actions across the world) support developing countries in an effort to end chaos, civil war, political instability, drought, famine, poverty, ethnic strife, and the like in the latter. However, donors' ultimate goal is to defend threats to their security and national interests. Therefore, apart from their economic and commercial interests, donors seem to be basically interested in the stability of aid-recipient countries given the basic assumption that "hunger breeds discontent, and discontent breeds instability" (Olaniyan [8]), no matter whether there exists stable dictatorial rules in these countries. For this reason, the study mainly takes into account realist paradigm claiming that it best explains the aid regime.

\subsection{The Politics of Foreign Aid}

Throughout its history, foreign aid has meant to provide worldwide development assistance that is assumed to lie at the heart of moral imperatives-donors' moral obligation to better the living condition of the poor in the developing world. Against this backdrop, however, the aid regime and its transformations cannot be seen in isolation of issues that fall under the headline of politics-power, security, ideology, foreign policy, national interest, and the like. Thus, "who uses aid, and for what?" is the crucial political question in foreign aid (White [9]).

Montgomery [10], on the other hand, shortly summarizes foreign aid as "a political force abroad and a political issue at home, irrespective of its successes and failures". For this reason, "[i]ts purposes and its achievements, its origins and its operations, its giving and its receiving, all involve conflicts of ideology and power" (ibid, italics added). This is particularly important in the realist account, which states that sovereign states behave in a way pursuing their national interests in an international system which is full of anarchy and danger (ibid). In fact, when official foreign aid came into being in the late 1940s, it was necessitated mainly by two political factors: "U.S. fear of communist expansionism and European imperial politics" (Wall [11]).

The proliferation of intractable challenges (notably terrorism) that have put the security and well-being of so- 
vereign states (mainly rich industrial nations) into a bigger question-especially following the end of the Cold War, coupled with the 9/11 Pentagon attack, donors, especially Western countries, find it necessary to ensure their security and well-being by diffusing democratization worldwide under the prescriptions of neo-liberalism (Rakner et al. [12]). Thus, politics, which is a primarily domestic factor both in the donor and recipient states, influences the conditions through which foreign aid programs are administered.

\subsection{Donors' Shift of Emphasis in the Late 20th Century: A Look at the Why and How of Democracy Assistance to Developing Countries}

For years, intense debates have been surfaced by scholars across the globe as to whether the poor has to choose between economic opportunities and political rights, i.e. whether democratization has to be deferred until national development objectives are met (Windsor [13]). The issue of which one of these should come first has been a major challenge for scholars in the field. Those, who put democracy before development, argue that poor countries can achieve an all-round development if and only if they go through democratization process first. In this regard, they cite some instances of countries that achieved their development goal having first engaged in democratization process. And, those who stress development as a precondition for democracy argue that poor countries should have to wait for democracy until they achieve their overall development. In fact, the experience of some Asian countries (notably South Korea and China) is presented as a justification for this argument. However, since the 1990s, a new consensus began to emerge emphasizing democratic governance not only as an end in itself but also as a key element of supporting development (ibid).

The attention of most Western policy-makers to the nature of political regimes in the developing countries is of relatively recent origin (Hout [14]). During the Cold War era, emphasis was not given to help developing countries solve their wide-ranging problems. As a result of Cold War power politics, Western industrial nations turned a blind eye and a deaf ear to the political repressions and violations of the fundamental rights and freedoms of people in the countries that succumbed to the former Soviet Union's sphere of influence. As a matter of fact, the attitude of governments and donor agencies (that belonged to either of the two super powers) towards developing countries was conditioned by the position of the latter in the bi-polar Cold War world. This was manifested, for instance, in the long-term friendship of the West with Mobutu's Zaire, and the superpowers' shift of loyalty between Siad Barre’s Somalia and Mengistu’s Ethiopia in 1977 (ibid).

The end of the Cold War, heralded by the fall of the Iron Curtain or "Berlin Wall" in 1989, bolstered an optimistic avenue for waves of political transformations, especially across the territories of the former socialist-bloc countries (IDEA [15]). The triumph of capitalism over socialism has, indeed, paved a fertile ground for the expansion of democratic institutions in the newly liberated Asian, Latin American, and African countries (these institutions include, for example, political parties, the media, and civic organizations that have received massive assistance especially from Western industrial nations) (ibid). As a result, democracy assistance has been institutionalized after the issue of "good governance" was initiated in the late 1980s by the World Bank as a new look in the development agenda.

Hence, the 1990s ushered the emergence of democratic promotion both as an objective of and a condition for development co-operation, with significant aid funds now allocated to it by bilateral and multilateral donor agencies (Crawford and Kearton [16]). Some of the areas of democracy assistance include:” i) elections and electoral processes; ii) political parties; iii) judicial reform; iv) civil society; and v) the media” [17]. Apart from the end of the Cold War power politics, there are some reasons for this fundamental shift of emphasis to democracy assistance as a major innovation in the global aid regime.

One basic reason is attributable to the ineffectiveness of economic and market-oriented stabilization programs of the late 1970s and of structural adjustment programs (SAPs) that were vigorously propagated in the 1980s, especially through the economic orthodoxy of "Washington Consensus" with its policy prescriptions, including free trade, fiscal restraint, prudent macroeconomic management, deregulation, and privatization (Williamson, 1990, in Santiso, [18]). In addition, the early global neo-liberal agenda did not pay attention to a country's political culture, its nature of government, and its peoples' participation in the body politic (Demmers et al. [19]). Consequently, the World Bank concluded, in its 1989 Report, that the cause for disappointing results of SAPs was the lack of the practice of democratic culture in the developing countries.

Secondly, democracy assistance is considered as an instrument to satisfy donors' motivations and interests, including foreign policy, security, geopolitical, humanitarian, diplomatic, and economic goals (Rakner et al., 
2008). Thus, it is highly reasonable to believe that donors, especially Western industrial nations (with national interests in their backside), have supported democratization efforts in the developing world being confident that democracy, as a system of governance, provides more benefits than authoritarian and totalitarian political culture.

Democracy assistance also contributes a lot in poverty alleviation through creating effective public institutions dealing with the poor and poverty. Democratic support has been revitalized following the establishment of the United Nations' Millennium Declaration, the Monterrey Consensus, and the Millennium Development Goals (MDGs). According to Demmers et al. (2004: 8), democracy assistance has the instrumental role in poverty alleviation that is basically underscored in the Poverty Reduction Strategy Papers (which is part of the program for debt reduction of Highly Indebted Poor Countries (HIPC)) that has been encouraged by the WB and the IMF from 1999 onwards.

Generally speaking, it has increasingly become compelling for Western donors to diffuse democratization worldwide within the context of liberal assumptions ultimately leading to realist considerations, especially in the today's world facing a multitude of problems that are basically exacerbated by technological advancement (for example, terrorism, piracy, criminal networks, civil war, and political instabilities that have put the security and well-being of nation sates in a bigger question). And this signals the very idea that global neo-liberalism could only successfully proceed in a credible and effective democratic environment.

\subsection{An Overview of Foreign Aid in Ethiopia}

Ethiopia is an aid-dependent country situated in the Horn of Africa region. "Aid dependence" is a term used to refer to "a situation in which a country cannot perform many of the core functions of government, such as operations and maintenance, or the delivery of basic public services, without foreign aid funding and expertise" [20]. The history of foreign aid in the country is slightly similar to that of the history of international aid, which began in 1947 when the Marshall Plan was used to reconstruct war-torn economies of Europe. Ethiopia is known to have started receiving foreign aid, in its official form, in 1950 (Haji [21]) when it was, for example, a recipient of the first World Bank assistance to Africa. However, the nature of aid given to the country was not initially "civilized, permanent, well organized, and wider in scope" like the nature of aid we experience today (ibid). In addition to being utilized for war and humanitarian crises, aid was given basically in response to Haile Selassie's government quest for restoration and consolidation of the Ethiopian state, which was ruined by the five years Italian invasion (ibid). Furtado and Smith [22] pointed out that when Ethiopia first entered into relations with donors in the 1950s, it did so as a sovereign state—one that had been established, in varying forms, for several hundred years-with its own domestic governance structures. In this respect it was quite unlike most other aid-recipient countries, which began receiving aid upon independence in the mid-1960s, in a context of weak domestic policy-setting structures, and almost as an extension of colonial/mother-country relations.

Because Ethiopia has been jealous of its sovereignty, it is true to say that its relations with donors have been conditioned by its own crises situations and by the nature of international political landscape and of strategic interest and ideology of great powers.

Accordingly, during the later years of Haile Selassie's reign, aid given to Ethiopia was slowly increasing as the West was building up good relations with the country; the latter was not ideologically hostile to the former. These relations were intensified after Ethiopia was found to be strategically important for the West (especially for the U.S., which established Kagnew Station in Asmara in 1943 for the sake of protecting its own interest in the Horn of Africa region and beyond) (Awetu [23]). In fact, the nature of aid given to the country was basically used for infrastructural development and for the restoration and consolidation of the then time government (Haji, 2013, personal communication). Later on, humanitarian assistance was given to rehabilitate the 1973/74 famine, which is known to have claimed the lives of so many Ethiopians.

For reason of ideology and poor human rights records, aid given to Ethiopia during the military regime was basically confined to humanitarian and relief purposes. For instance, the U.S. officially withdrew its voluminous support to Ethiopia in 1977 on account of the former Soviet Union's establishment of officially declared relations with Ethiopia (Awetu, 2013, personal communication). After the EPRDF assumed political power in 1991, donors' relations with the country (which were suspended during the military regime for the above reasons) were renewed with greater energy and intensity. Accordingly, the scope of foreign aid has been getting wider and new emphasis has been given to other areas, including democracy and human rights, within the wider development agenda. 
Generally, donor partners to Ethiopia and the amount and type of aid that the country has received have been in the state of fluctuation with the passage of time. This was because these relations were not of reflections of historical ties that were currently maintained by other poor aid-recipient countries, which were formerly under the yoke of colonization by the imperial powers (Furtado and Smith, 2007: n.p).

Needless to say, the basic reason for why Ethiopia receives development assistance is that the country is among the poorest countries in the world, ranked, for instance, on the 2007 United Nations' Human Development Index, $171^{\text {st }}$ out of 182 countries. This implies that Ethiopia receives external assistance since it qualifies for the Highly Indebted Poor Countries (HIPC) designation. For this reason, humanitarian assistance has been the predominant one in contrast to the different forms of aid that the country has received (DAG [24]). The country receives this form of aid, especially at times of natural calamity (for instance, drought and famine that seriously ravaged the country in the 1970s and 1980s and left many Ethiopians starved and even dead out of food shortage). In addition, this type of aid goes to Ethiopia to rehabilitate the country after crises and political turmoil (for example, during the 1974 fundamental revolution and devastating wars between the Derg and the rebel fighters and, later between Ethiopia and Eritrea between 1998 and 2000).

In fact, it is hard to speak with certainty about the volume of development assistance Ethiopia receives because, as in many aid-recipient developing countries, much financing is provided outside of official government channels (Furtado and Smith, 2007: n.p). The overall ODA inflow to Ethiopia has been increasing steadily from the 1960s onwards. With the turn of the twenty-first century, the overall aid inflow to the country has risen up (this move has been particularly stimulated by the country's commitment to end poverty, which is geared towards the achievement of the Millennium Development Goals (MDGS) and Poverty Reduction Strategy Papers (PRSPs) (Demmers et al., 2004: 8)). However, Dessalegn and Ayenew [25] argue that assistance to democratization in the country is negligible and has been getting scanty especially since the mid-1990s. One basic reason for this problem is that donors have the usual practice to reinstate their direct budget support and rely on overall development activities when they encounter unconvincing democratic governance trends (as was evident in the post-2005 national elections popular unrest) (DAG, 2010: 9). Therefore, support for this area is discouraging.

The following figures (Figure 1 and Figure 2) show an overall picture of the evolution of Official Development Assistance that Ethiopia received in the periods between1960 and 2003, and between 2004 and 2008.

As can be shown in Figure 1, the average flow of aid from 1960 to 2003 was increasing with minor and major fluctuations before and after 1985, respectively. The aid picture captured the highest figures in the early 1990s, i.e. when the conflict between the military regime and rebel fighters was over. Increased trend in aid flow terminated in the mid-1990s and reached its trough during the Ethio-Eritrean wars, i.e. from 1998 to 2000. However, when the war was over, aid had started to increase rapidly and reached its peak in 2003. Generally, the volume of aid inflow to Ethiopia was very massive especially since the late 1980s, i.e. when the Derg era was getting over.

As can be shown in Figure 2, net ODA inflow to Ethiopia from 2004 to 2006 was almost stagnant. However,

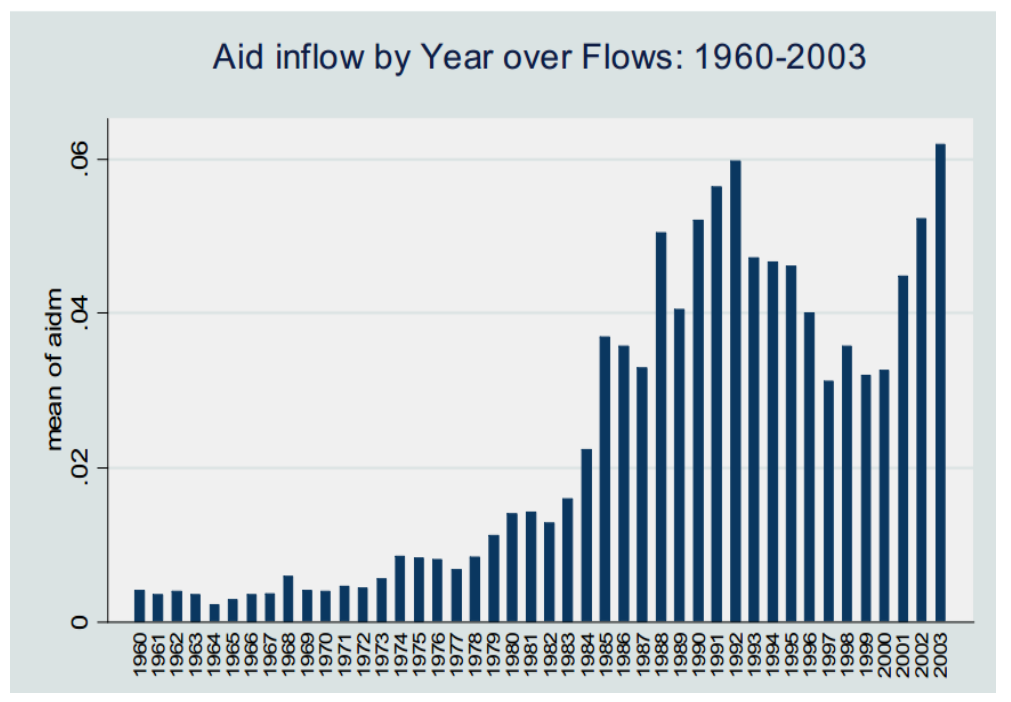

Figure 1. Average Aid Inflow to Ethiopia by Year: 1960-2003 (Constant USD Millions). Source: OECD, n.d, in Adugna [26]. 


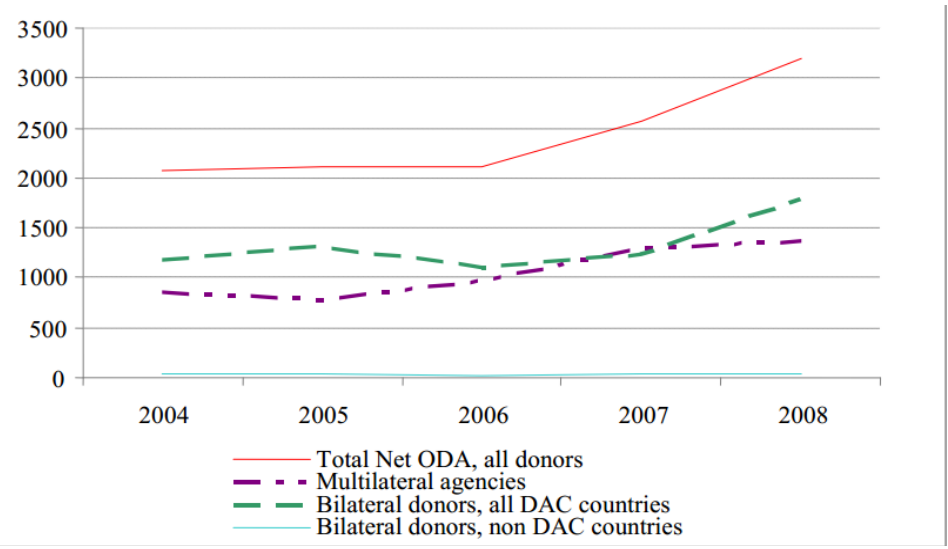

Figure 2. Net Aid Disbursements to Ethiopia: 2004-2008 (Constant USD Millions). Source: DAG, 2010: 9.

after 2006, it increased very rapidly and reached its peak (beyond US \$ 3000 million) in 2008. In fact, bilateral donors' (DAC member states) contributions exceeded that of multilaterals' followed by assistance from nonDAC member bilateral donor countries. Multilateral and DAC member bilateral donor countries had inverse relations from 2004 to 2008 and intersected each other slightly in 2007, with the latter providing the highest volume of assistance before and after 2007.

Generally speaking, donors' policy toward Ethiopia is shaped by some factors, including the level of the country's poverty, with a significant number of people struggling to feed themselves year after year, the strategic position of the country as a peaceful and stable state in the Horn of Africa (which makes the country a key ally of the West in this region experiencing intractable challenges, including conflicts, poverty, humanitarian and other shocks), and, though subject to contention, the encouraging economic growth that Ethiopia has made to reduce poverty and unemployment (Human Rights Watch [27]).

\subsection{A Primer on Ethiopia's Institutional and Policy Setting}

After the ousting of the much hated Derg regime in 1974, Ethiopia has adopted a parliamentary system of government and a federal state structure through which nine constitutionally autonomous regional states and two city administrations (Dire Dawa and Addis Ababa) were created. As enshrined under the 1995 FDRE constitution, there is a doctrine of separation of powers and check and balance horizontally between the three organs of government, namely the legislative, the executive, and the judiciary and separation of powers vertically between the federal government and the federating units. At the federal level, the legislative body reflects a bi-cameral parliament, which is the locus of power in a parliamentary system, consisting of the House of Federation and the House of Peoples' Representatives. The power of designing the overall policies and strategies of the country is entrusted to the House of Peoples' Representatives. However, there are arguments that run into and against issues of institutional autonomy and popular sovereignty and their ramifications for laws, rules, and regulations governing government-people relations in the country.

It is hard to deny that the culture of democracy has been more or less practiced in Ethiopia mainly in the post1991 period. However, what makes the issue of democracy debatable in the country is whether it has reached to the level expected by the Ethiopian people taking into consideration domestic realities (for example, popular awareness and economic strength) and transformations and speeds of change worldwide. Some people argue that democracy, which must be seen as a process, has been getting improved in the country; it is, therefore, believed to be a step forward in the right direction (Yissma [28] and Berhanu [29]). This does not mean, however, that there are no challenges to it, including the lack of the culture of political tolerance, democratic governance, popular awareness, and the prevalence of poverty and the like.

Still, some others contend that the current government has to be praised since it has rescued the country from the military regime's 17 years of traumatic and atrocious rule. Further, the government has brought to the Ethiopian people about relative peace and stability, and has ensured a constitutional and democratic order through which each nation has enjoyed its right to self-administration up to secession, use its own language, use and de- 
velop its own culture and so forth (Haji, Yissma and Berhanu, 2013, personal communication).

Nevertheless, when asked to reply me whether there existed institutional autonomy in the country thereby taking the National Electoral Board as a case in point, the Board’s Public Relations Officer, Yissma Jirru, stated that the institution was an independent, impartial, and constitutional body "absolutely" free from interventions from anybody including the government. If it is, indeed, independent, does not the role of the Prime Minister in the appointment of Board members (as is stipulated under Art. 102 (2) of the FDRE constitution) contravene with the Board's autonomy and politicize its status? I inquired. Yissma's reply was that the fact that the Prime Minister nominates Board members did not affect the Board's autonomy basically because clear discussions were held by different bodies, including opposition parties, regarding the competency and non-partisanship of these candidates before their final appointment by the House of Peoples' Representatives (HPR). But, I do not agree with Yissma's view, altogether. Because, the Prime Minister's intervention in the appointment of Board members, I strongly believe, sheds light on the Board's status - it has made the Board inextricably linked with politics.

On the other hand, institutions like the police, the army, the state media, security institutions, the bureaucracy and capacity building, and the judicial sector (which are powerful instruments and arms of the government) are criticized of being "mere instruments" of the ruling party serving its own interests (Mushe [30] and Merera [31]).

Appreciating that the government's establishment of constitutional system and the culture of multiparty democracy as a welcome initiative, the USAID’s Democracy and Governance Senior Advisor, Awetu Simesso (2013, personal communication), argues that the fundamental guidelines and principles enshrined under the constitution are too far from implementation. The major challenge, in his viewpoint, is the lack of institutional autonomy and of separation of powers and checks and balances between and among core government organs; the judiciary is not still independent, the executive is not subordinate to the parliament and dominates everything in the state. Moreover, because of the fact that the state and the ruling party are highly intertwined, the interests and activities of the government and the ruling party (EPRDF) have become almost inseparable (Human Rights Watch, 2010: 17). The main cause of these problems is that the incumbent government, which has more and more reverted to autocratic and totalitarian rule, especially since the 2005 national elections, lacks a political will or commitment to allow meaningful democracy to be maturing in the country, except for practicing pseudo-democracy (Meyer [32]).

The Ethiopian government holds the view that rules, laws, and regulations of the country are usually designed thereby primarily taking into consideration the interest of the citizenry. So, the government stresses that rules and regulations are strong in regulating or governing government-people relations in the country. And, in the government's opinion, those who label the regime as a "pseudo-democrat", "repressive” and the like are "anti-development”, “anti-peace”, “terrorists” and the like (Meyer, 2012: 53). This, I believe, reflects one dominant factor for the problem of the lack of clear communication affecting government-people relations, which, in turn, questions the acceptability of the country's laws, rules, and regulations.

For this reason, the Parliament (which is supposed to reflect the interests of the Ethiopian people) is not, arguably, entirely autonomous. It formulates laws, rules, and regulations having first received the executive's free will. I believe that any law or proclamation enacted with actual or perceived intervention by the executive or other bodies usually skews in favor of the interest of governing elites other than the people whom policy decision-making and implementation processes affect. Thus, it goes without saying that any law that does not reflect the interest of people cannot be legitimate and relevant by any standard. However, as critics argue, enacting laws or proclamations to serve as a legal weapon in suppressing the citizenry is disappointing and destructive (Merera, Mushe and Wondimagegn [33] and Awetu, 2013, personal communication).

For some, the NGOs law and the anti-terrorism law, which were enacted in 2009, are used to stifle both actual and potential threats to the government's power survival. In the name of these laws, the government is violating the human and democratic rights of the Ethiopian people by jailing and arresting people who are found in the government's "annals of terrorists" and restricting the activities of NGOs operating in the country (ibid). The main reason for this is that the anti-terrorism law is too broad to the international standard, and has, therefore, several connotations and this makes everybody to desperately suspect himself or herself whether he/she is a terrorist, whereas, the new NGOs law is meant to disturb the activities of civic organizations operating in the country (Awetu, 2013, personal communication). Awetu further suggests that since these two laws reflect an unfortunate practice unfolding in the country, they need to be reinvestigated and improved to strike the balance be- 
tween domestic realities and the international standard. On the part of the government, however, it firmly maintains the argument that these laws are up to the international standard. For instance, Ethiopia's late Prime Minister, Meles Zenawi, did, once upon a time, address the federal parliament that the new anti-terrorism law was adopted from Britain, word by word, phrase by phrase, and, if exaggerated, including full stops (Wondimagegn, 2013, personal communication). Asked whether the Human Rights Commission, an institution set up to monitor and document human rights situations in the country, has so far evaluated the constitutionality (acceptability) of these two laws, the Commission's Information Communication Directorate Director, Berhanu (2013, personal communication), replied that the Commission had not yet finished its business to arrive at its final judgment on the issue, adding that it has had insufficient time to do so mainly because of work overload. Of course, this kind of response is not expected from a higher government official, like Berhanu. Even though it was possible for him to provide solid reasons and evidences, he preferred to address the question resorting to mere excuses.

The influence, through various means, of the general public in the formulation of overall policies and strategies of the country is frustrating. Instead, the government talks and decides alone and the people submissively receive and implement orders and commands imposed on them from above (Merera, 2013, personal communication). Apparently, opposition political parties have no direct influence (particularly through parliamentary debates) on governmental policies and strategies and offer their alternative policy options, especially in the post-2010 national elections, for the ruling party has "technically" controlled almost all parliamentary seats by chasing them all out of the political game (ibid). This all suggests that clear and effective line of communications between the government and the general public are lacking. For this reason, government-people relations in the country are overshadowed by the lack of clear communications at best and fear and suspicion at worst.

The implications of weak rules and regulations governing government-people relations in the country are obvious. First, it violates the principle of accountability and transparency. This, in turn, leads to governance problems, especially to the widespread of corruption, which has now become a very sensitive issue in the country (in fact, government officials are increasingly becoming corrupt and the government, accepting that such a dangerous problem exists, is engaged in firing up officials on account of their corrupt behaviors and actions-currently, we were told that some high ranking government officials, especially in the Ethiopia's Revenue and Customs Authority, fired up from their power and, even sent to jail, on account of corruption (Ethiopian Television News, May, 2013). It must be also recalled that Ethiopia’s late Prime Minister, Meles Zenawi, once upon a time dubbed corrupt officials "state thieves"). The opposition parties, while acknowledging that such problem exists, are not wholly satisfied with the measures being taken since these measures, they strongly argue, basically "target the small fishes while the big fishes continue to swim” (Merera, 2013, personal communication).

All this has a significant impact on the flow and use of aid money in the country. Because, in a system where corruption is rampant, it is hard to think that democracy assistance could fully achieve its intended purposes. In addition, it is argued that the unsatisfactory results of worldwide democratization efforts, including democracy assistance programs, are most often attributable to domestic conditions or structural hurdles that make it difficult for democracy to be established or to survive (Brown [34]).

\subsection{The Role of Foreign Aid in Strengthening Democratic Institutions}

Donors' strategy toward Ethiopia, which was tightly controlled during the military regime, has relatively enjoyed warm reception ever since EPRDF's ascendance to political power in 1991 (Haji, 2013, personal communication). However, the volume and scope of democracy assistance, compared to other forms of assistance, is believed to have been insignificant in the post-1991 period.

According to Dessalegn and Meheret (2004: 13), it is difficult to get cumulative figures on democracy assistance to Ethiopia and distinguish with certainty what has gone to governance programs and what to non-governance programs. One basic reason, the authors argue, is that assistance to this area is widely channeled through NGOs or civil society organizations in general. Secondly, donors give very little attention to this area and this is reflected when they shift their concern and support from this area to other development and humanitarian issues, particularly in crises situations. For instance, following the 2005 political turmoil, the World Bank and donor partners in the Development Assistance Group (DAG) (which is a consortium of all major donors to Ethiopia) stopped their direct budget support to the Ethiopian government in favor of Protection for Basic Services (PBS) assistance to such five sectors as roads, health, education, water, and agricultural extension (Human Rights Watch, 2010: 19-20). The reason for this basic shift of emphasis is associated with the post-election vi- 
olence and public unrest that was embarrassing for many donors.

Currently, a more formal and institutionalized democracy assistance is provided by DIP. The Democratic Institutions Program (DIP), a consortium of bilateral and multilateral donors started in 2008, is a five-year program coordinated by the UNDP with an objective of supporting key democratic institutions that play a role in strengthening institutional frameworks of democratic governance [35]. Thirteen donors that provide assistance, through DIP, to key democratic institutions in the country include Austria Development Cooperation, Canadian International Development Agency (CIDA), Denmark, Irish Aid, Italian Cooperation, The Netherlands, Norway, Office of the High Commissioner for Human Rights, Swedish International Development Cooperation (SIDA), Department for International Development (DFID), United States Agency for International Development (USAID), United Nations Development Program (UNDP), and the European Union (ibid). And, the democratic institutions supported by DIP include the Ethiopian Human Rights Commission (EHRC), the National Electoral Board of Ethiopia (NEBE), the Ethiopian Institute of Ombudsman (EIO), the Federal Ethics and Anti-Corruption Commission (FEACC), House of People's Representatives (HPR) and Regional State Councils (RSCs), House of Federation and SNNPR Regional Council of Nationalities, and the Office of Auditors General and Regional Offices of Auditors General (DIP Annual Report [36]).

Through enhancing the capacity of these institutions to be effective, sufficient and responsive in promoting and protecting the rights of citizens and through empowering citizens to be active and effective participants in the democratic process, DIP is doing a more or less good job so as to help the country promote human rights and democracy (DAG, n.d). Most importantly, as a leading UN agency for promoting democratic governance, UNDP is playing a key role towards the realization of Millennium Declaration principles and deepening and widening democracy in the country through a number of programs and projects that actually support the capacity of these democratic institutions (UNDP [37]). These programs and projects are implemented within the context of the UN-wide Good Governance Program as stipulated in the United Nations Development Assistance Framework (UNDAF), which emphasizes the principles of promoting good governance that are underscored in the Plan for Accelerated and Sustainable Development to End Poverty (PASDEP) (ibid). And the forms of assistance to democratization process in the country include human rights and advocacy trainings, judicial sector reform and conflict mitigation, trainings to journalists, support to political parties and electoral assistance, support to the media, financial and capacity building support to the democratic institutions, and the like. With regard to conflict mitigation, the USAID is a major donor partner concerned with improving, in collaboration with the Ministry of Justice, the judicial sector by providing trainings for federal and regional courts and police officials in the context of international and national human rights law and institutional administrative regulations and helping mitigate conflicts in different areas, like Somali, SNNP, Oromia, in different Universities and other areas (Awetu, 2013, personal communication).

Although insignificant, DIP assistance has achieved some outcomes. And the Democratic Institutions are more or less discharging their responsibilities thereby investigating and resolving human rights violations, corruption, and maladministration cases. For instance, in the first half of 2010 alone, the FEACC was able to retrieve 78,650 $\mathrm{m}^{2}$ of land in Addis Ababa that individuals held without due process (DIP Annual Report [38]). During the same period, the Commission retrieved and deposited into government's treasury a sum of ETB 7,532,494 embezzled by individuals (ibid). Basically, the Commission's effort in fighting corruption has been supported by the promulgation of the Asset Registration Proclamation. In this regard, it is indicated in the Report that Prime Minister Meles Zenawi was the first to register his assets [in public?] to give the necessary impetus for the implementation of the Proclamation (ibid). Though a welcome initiative, FEACC's task is criticized very much by the public for one outstanding reason. It is said that FEACC is not free from political interventions coming both from within itself and outside. In other words, it is controlled by self-serving ruling cliques and, thus, could not dare to continuously register and publicize the personal assets and belongings of this group of people. Therefore, its activities are not being carried out in the public domain.

The Report further pointed out that the public awareness is enhanced through the establishment of regional branches and collaborations with civil society organizations. For instance, EIO has collaboration with Regional Grievance Centers, FEACC is working cooperatively with regional anti-corruption bodies, EHRC has partnership with CSOs, and there exists constituency outreach by the Parliament. Regarding the achievements made by the National Electoral Board of Ethiopia (NEBE) in the May, 2010 parliamentary elections, it is stated that the Board mobilized and registered a total number of 31,926,520 — in contrast to 25,000,000 voters registered for the 2005 parliamentary elections (15,252,240 (47.8\%) female and 16,674,280 (52.2\%) male) citizens to vote in the 
2010 general elections (ibid). Out of this voter turnout, 29,832,190 (93.4\%) cast their votes (ibid).

However, there are some basic challenges to DIP assistance. These include, like, for example, awareness problem (the lack of knowledge and understanding, especially on issues of human rights and democracy both on the part of the Ethiopian people and implementing institutions); maladministration practices; and financial deficits and technical and operational difficulties (like, for example, late disbursement and receipt of funds, delay in procurement, and delay of reports from the field) facing IPs (Haji, Berhanu and Yissma, 2013, personal communication). Currently, such challenges for democratization drive seem to have been exacerbated by the emergence of dominant party system and the government's heavy reliance on using the country's resources (both human and material resources) for overall development activities, which appears to make democracy incidental. This has now become evident, especially in the government's extensively stretched development agenda centered on the construction of Grand National Dam-Ethiopia's Renaissance Dam, which is now underway.

Aid coordination in Ethiopia is carried out by the Ministry of Finance and Economic Development (MoFED), particularly through its Department of Economic Cooperation (UNDP [39]). Donor consultations on development cooperation matters are undertaken through the Development Assistance Group (DAG). The Development Assistance Group-Ethiopia (DAG-Ethiopia) "is a permanent body established in 2001 through which donor agencies keep each other informed about their programs and discuss both policy and implementation problems with Government officials. The DAG membership includes over 30 bilateral and multilateral development cooperation agencies, including United Nations agencies" (UNDP, 2006: n.p). This organization prepares and coordinates high-level consultations between donors and the Ethiopian government and the biannual meetings of the Consultative Group for Ethiopia (ibid). Aid planning and implementation is conducted in the context of "democratic decentralization" through which regional and local governments are mandated to prepare and implement, in accordance with general rules and regulations established by the federal government (through MoFED), their own development plans (Haji, 2013, personal communication).However, many critics doubt the autonomy of regional and local governments as it appears that these government bodies are subject to strict interventions from the central government.

As regards DIP's role, implementation of the program is carried out through an institutional mechanism called National Implementation Modality (NIM). This is a basic framework developed in accordance with the UN General Assembly Resolution [47/199] of December 1992 on program execution in program countries (DIP Annual Report 2010: 16). Alongside the coordination and management of donor funds, the overall DIP financial management rests with UNDP (ibid). In fact, UNDP's development assistance programs are derivations of UNDAF and DIP (ibid). In the context of National Implementation Modality, the Coordination Committee (CC), the Technical Committee (TC) and the Coordination Unit (CU) are expected to be responsible for the management of DIP program (ibid). To ensure that assistance is used for its intended purpose, proposal development and progress reports are provided, mainly through MoFED to the donors (Haji, 2013, personal communication). In addition, assistance is not given to the IPs overnight; instead, it is provided regularly (basically on the basis of progress evaluations) till the end of the DIP program every five years. Generally, DIP program, which is a fiveyear assistance to the IPs, is administered to strengthening the IPs (thereby evaluating their financial, organizational, and technical capacity through scheduled visits and follow ups) on the basis of the above institutional framework.

However, given the fact that donors' support basically goes to governmental institutions, the basic problem lies here in the confusion that whether donors are really concerned about democracy to be maturing in Ethiopia and have addressed the allegations that their aid to the country is one-sided, i.e., helping the ruling party to stay in power (Wondimagegn, 2013, personal communication) while the regime is at ease with them. Moreover, clear, practicable, and mutually agreed upon mechanisms (according to which the Ethiopian government and democracy assistance partners can take measures on account of failures to materialize the terms of agreement) are still lacking.

\subsection{The Role of Ideology in Shaping Foreign Aid in Ethiopia}

The EPRDF's ideology is Revolutionary Democracy-equivalent to democratic centralism-which underscores the very assumption that the party is both the engine of development and the forum for social discourse and democratic dialogue. While individual rights become incidental in contrast to the much wider societal and governmental matters, group rights are preferred over individual ones (Human Rights Watch, 2010: 13). 
Critics do not appreciate this ideology claiming that it has failed so far and that it is hard to fuse revolution and democracy together. For all practical reasons, the EPRDF is accused of being socialist-oriented since it gives much more weight to development than democratic ideals (Wondimagegn, 2013, personal communication). My concern here is not whether the government is socialist, but it is to evaluate the extent to which the government gives emphasis to democracy vis-à-vis its position on the issue of development.

Hussein [40], while seeing the debate in light of land property ownership, argues that one should not be amazed with the EPRDF's decision to uphold the Derg regime's socialist-leaned property ownership policy without paying attention to the primarily agrarian nature of the Ethiopian people and the degree to which the mode of rural land tenure is a controversial political issue in the country's recent history. However, the author does not accept the claim that the government is completely socialist-oriented.

As a matter of fact, the regime cites Asian countries (notably South Korea and China) as models of development strength that can be achieved through state-centered development paradigm. This is so in spite of its experiences in allowing, at least in principle, a democratic system-multi-partism, competitive democracy, and the like. So, the incapability of the regime to meaningfully exercise democratic ideals has made it to be known with pseudo democracy than with real practices. Some consider democratic centralism as an ideology that favors undemocratic political culture (Merera, 2013, personal communication).

The government, on its part, argues that democracy in Ethiopia is now maturing and people are enjoying their rights and freedoms (which were suppressed by the previous regimes, altogether), including the right to self-administration, freedom of religion, language, association, movement, the right to use and develop one's own culture, the right to use one's own property, and the like (Berhanu and Yissma, 2013, personal communication). However, this welcome initiative has been overshadowed as the ruling party has given much more weight to the overall development imperatives as a prerequisite to democracy, albeit not expressed officially. In fact, the EPRDF strongly maintains that democracy and development are complementary issues that cannot be separated (Mushe, 2013, personal communication). Nevertheless, our research findings show contrary to the official claim. Because, given poverty as the country's daunting challenge, the regime seems to be interested in poverty reduction much more than giving, at least, equal importance to issues of human rights and democracy. A shiny example which can be mentioned here is the overambitious Grand Renaissance Dam project, now underway.

This all suggests that ideology affects, in one way or another, the flow and allocation of foreign aid. Despite the fact that it has accepted some elements of liberal prescriptions, the Ethiopian government has not yet fully resorted to liberal democracy. In fact, the Ethiopian government is known to have been trapped in between democratizing the Ethiopian state and society on the one hand and staying in power on the other (Merera, 2013, personal communication). And, the second motive appears to be much more convincing and compelling. Because of these factors, ideological differences between the government and western donors might have altered the formulation and implementation of aid policy agendas in the country. As explained earlier, relations between the Ethiopian government and donors are overwhelmingly dominated by the former (Haji, 2013, personal communication). Donors have no any significant influence on the country. Two basic reasons can be pointed out for this. Firstly, since Ethiopia is independent historically, there is no any former colonial power that feels compelled to influence the country through various mechanisms. Secondly and, probably most importantly, Ethiopia is jealous of its sovereignty which has been historically defended from any external threat (ibid).

In conclusion, the Ethiopian government's heavy reliance on development activities (which is a reflection of its ideology) and its very little attention to democracy coupled with donors' reluctance to pressure the government to advance the cause of democracy and human rights in the country must have so far made democracy assistance to the country a futile business.

\subsection{Lessons Learnt}

In spite of the fact that donors (especially DIP partners) are performing more or less a good job in giving a coordinated assistance to some governmentally established democratic institutions, such assistance is judged to have fallen short of providing formal support to other equally important or crucial democratic institutions, namely the media, civil society organizations, and opposition political parties. Ironically, the donor community is enthusiastic to encourage democratic institutions in the assumption that the road to democracy lies not in revolutions and violence but in the active participation of civil society in the political undertakings (Dessalegn [41]). However, these irregularities have put donors under criticisms coming from different sources. In fact, one could not deny a 
very strong and active role played by civil societies and political parties in democratization process. For instance, on a publication of the Center for Democracy and Civil Society, Elone [42] stated that among the many contributing factors for the democratization of African states, civil societies played a key role in toppling down autocratic and totalitarian political culture and setting the stage for competitive democracy. The same is also true for political parties, which have a central place in modern day democracy.

As a matter of fact, political parties, NGOs and the media, operating in the country, are not allowed by the law of the land to seek any direct or indirect assistance from external sources (Merera and Mushe, 2013, personal communication). In an interview with Haji, I was told that NGOs are not allowed to receive external assistance because of the lack of capacity and fear of mismanagement (especially corruption). The new CSOs law prevents NGOs from generating more than 10 per cent of their income from external sources and from welcoming foreign citizens as their members (Center for International Human Rights [43]). For instance, the Charities and Societies Proclamation [44], in its Article 2 (2), makes it explicit that charities that are formed in accordance with the Ethiopian constitution, all of whose members are Ethiopians, generate income from Ethiopia, totally controlled by Ethiopians, and receive less than ten percent of their total revenue from external sources are referred to as Ethiopian Charities or Ethiopian Societies. However, charities and societies that are established by the Ethiopian laws consist of members who reside in Ethiopia, and earn more than ten per cent of their income from external sources or from foreign donor agencies and countries are referred to as Ethiopian Residents Charities or Ethiopian Residents Societies.

For this reason, this law has put under strict scrutiny the NGOs' constitutional right to freedom of association, movement, and expression and prohibits international NGOs from working in the areas, including, among others, providing assistance to the poor, conflict resolution and peace building, democratization, human rights-related advocacy, gender and disabilities (Jubilee Campaign Report [45] and Amnesty International [46]). The Ethiopian government, on its part, argues that the new CSOs law is important to address perceived insufficiency in the existing legal system, encourage financial transparency and accountability, and have appropriate management of civic organizations (Amnesty International, 2009). Thus, this is the most disappointing and politically motivated law which is preventing the emergence of potential civic organizations and also paralyzing day-to-day operations of the already established ones.

As explained earlier, the anti-terrorism law, which is subject to numerous interpretations is also criticized for deterring the activities of individuals, opposition political parties, and NGOs. Regarding opposition parties, critics argue that so many opposition political party officials, supporters, and members have been harassed or detained in the name of such ambiguously stated law (Merera and Mushe, 2013, personal communication). In fact, in June 2011, the Ethiopian Parliament employed it to designate five dissident groups (that are not legally accepted by the government), namely OLF, ONLF, Ginbot-7, al-Qaeda, and al-Shabaab as terrorist organizations (Meyer, 2012: 54).

Moreover, the contribution of press freedom, which has a critical role in fostering democracy, has also become very questionable. Recently, so many newspapers and magazines are closed and many journalists are also prevented from their activities (even many of them are now serving prison sentences) (Merera and Mushe, 2013, personal communication). All this suggests that NGOs, opposition political parties, and the media (which are supposed to have a dominant role in democratization process) are currently very weak mainly because of stiff pressures from the government. Under such a painful environment, it is hard to expect that external assistance may function well in Ethiopia, which is a country heavily dependent on external assistance.

Basically, assistance to political parties and NGOs (which mainly goes through the NEBE), in consolidating democratization, is general during elections, especially during parliamentary elections (Merera, Mushe and Wondimagegn, 2013, personal communication). Of course, electoral assistance to political parties is not provided without facing problems. For instance, this assistance always runs the risk of discrimination and mismanagement that makes opposition political parties have a very little share on it (Merera, 2013, personal communication). What is more, the assistance allocation criterion is based on parliamentary seats, now virtually totally controlled by the ruling party. This has enabled the ruling party to take the largest share of the aid money in the absence of the opposition parties in the parliament, even though this is not good for a country where there are so diverse societies with their different interests that need to be reflected and protected by different political parties (ibid). On the contrary, some argue that any external assistance that is given to the political parties through the Board has been impartial or nondiscriminatory (Yissma, 2013, personal communication).

In addition to the above mentioned allegations that electoral assistance is largely used by the ruling party for 
its own political manipulations, the government is also criticized for using all kinds of unlawful actions against its people before, during, and after elections (these include pressures on opposition candidates, intimidation and harassment of voters, manipulation of the counting and reporting of election results and the like) (Pausewang et al. [47]). In spite of being criticized for being lopsided and reluctant to end discrimination against opposition candidates, the Electoral Board is appreciated for its praiseworthy logistical accomplishment in election times, given the transportation problems and harmful condition of many roads (ibid: 16). Noticeably, the size of international election observers and monitors (who usually come to Ethiopia to observe and judge elections against international best practices) is too frustrating; because the ratio is usually about 300 observers to 43,000 polling stations (Merera and Wondimagegn, 2013, personal communication).Their number is, of course, too few to cover such numerous polling stations. Furthermore, internal election officers and monitors are criticized of being "hand-picked cadres" of the ruling regime (Merera, Mushe and Wondimagegn, 2013, personal communication). If elections are conducted under this set of circumstances, they cannot be free, fair, and constitutional and this may contribute to making democracy assistance a futile exercise.

\section{Conclusion}

Development assistance has had wider implications in the dynamics of the social, economic, and political systems of the Ethiopian state and society. This article indicates that the aid regime in Ethiopia has been impacted by issues of ideology, national interest, sovereignty, weak rules and laws, corruption, and weak mechanisms that govern relations between the Ethiopian government and donors. This has emerged out of some compelling factors. For one thing, there is no any former colonial power that feels compelled to profoundly influence the country. In addition, donors do not seem to be keen to conduct their activities keeping their promises. Instead, their priority is to pursue their real intentions (soaked in their foreign policy objectives) that emanate essentially from issues of national interest, security, and geopolitics. That is why their responses to allegations of human rights violations in the country have remained muted and disappointing. Secondly, Ethiopia, being historically an independent state, has been jealous of its sovereignty, and this has become inconsistent with donors' multiple interests. What is more, the incumbent regime does not appear to be really committed to the cause of democracy, freedom, human rights, and good governance. Many critics contend that using state property for political manipulations and staying in power underscores the will and whim of the EPRDF-led government. The corollary of this is obvious. It breeds undemocratic system, weak rules and laws, corruption and instability. Most importantly, it paralyzes relations between the Ethiopian government and the donor community. Against this backdrop, however, an institutionalized form of democracy assistance, currently provided by the Democratic Institutions Program (DIP) to some governmentally established institutions, underscores the evolving face of democracy assistance in Ethiopia, albeit criticized by some for favoring governmental institutions at the cost of non-governmental organizations.

\section{Acknowledgements}

The author would like to express his warmth and deepest thank to such institutions as the Ethiopian Human Rights Commission, the Electoral Board of Ethiopia, the Ethiopian Ministry of Finance and Economic Development, the Ethiopian Federal Democratic Unity Forum (MEDREK), All-Ethiopia Unity Party, the Ethiopian Democratic Party, and the United States Agency for International Development for their invaluable cooperation in providing all the necessary firsthand data for the research. The author is also grateful to Dr. Hussein Jemma for his commendable guidance provided throughout the entire course of the study. In fact, this study would have been incomplete without the express and tacit contributions made by the above resource institutions and persons and by other anonymous individuals.

\section{References}

[1] Thorp, W. (1971) The Reality of Foreign Aid. Praeger Publishers, New York.

[2] Jifar, T. (2002) The Impact of Foreign Aid on Public Spending: The Case of Ethiopia. MA Thesis, Addis Ababa University, Addis Ababa.

[3] Barratt, B. (2008) Human Rights and Foreign Aid: For Love or Money? Routledge, London.

[4] Carbone, M. (2007) European Union and International Development: The Politics of Foreign Aid. Routledge, London. 
[5] Cosgriff, B. (2001) ODA: Official Development Assistance or Opportunity, Duty and Agenda? A Comparative Analysis of Japan and Australia as Foreign Aid Donors in the South Pacific, 1976-2000. MA Thesis, University of Canterbury, Christchurch.

[6] Lancaster, C. (2007) Foreign Aid: Diplomacy, Development, and Domestic Politics. The University of Chicago Press, Chicago.

[7] Van Belle, D.A., Rioux, J.-S. and Potter, D.M. (2004) Media, Bureaucracies, and Foreign Aid: A Comparative Analysis of the United States, the United Kingdom, Canada, France and Japan. Palgrave Macmillan, Basingstoke.

[8] Olaniyan, R.O. (1996) Foreign Aid, Self-Reliance, and Economic Development in West Africa. Praeger Publishers, Westport.

[9] White, J. (1974) The Politics of Foreign Aid. The Bodley Head, London.

[10] Montgomery, J.D. (1962) The Politics of Foreign Aid: American Experience in Southeast Asia. Frederick Praeger, New York.

[11] Wall, D. (1973) The Charity of Nations: The Political Economy of Foreign Aid. Macmillan Press, London.

[12] Rakner, L., Menocal, A.R. and Fritz, V. (2007) Democratisation's Third Wave and the Challenges of Democratic Deepening: Assessing International Democracy Assistance and Lessons Learned. Working Paper 1.

[13] Windsor, J.L. (2008) Mainstreaming of Democracy and Governance in Foreign Assistance. In: Picard, L.A., Groelsema, R. and Buss, T.F., Eds., Foreign Aid and Foreign Policy: Lessons for the Next Half-Century, M.E Sharpe, New York, 414-424.

[14] Hout, W. (2007) The Politics of Aid Selectivity: Good Governance Criteria in World Bank, US and Dutch Development Assistance. Routledge, London. http://dx.doi.org/10.4324/9780203945780

[15] IDEA (2010) International Institute for Democracy and Electoral Assistance Report: Twenty Years of Western Democracy Assistance in Central and Eastern Europe. International Institute for Democracy and Electoral Assistance, Stockholm.

[16] Crawford, G. and Kearton, I. (2001) Evaluating Democracy and Governance Assistance. ESCOR Research Report, No. 7894.

[17] Rakner, L., Menocal, A. and Fritz, V. (2008) Assessing International Democracy Assistance: Key Lessons and Challenges. Overseas Development Institute, Project Briefing, No 14.

[18] Santiso, C. (2001) Good Governance and Aid Effectiveness: The World Bank and Conditionality. The Georgetown Public Policy Review, 7, 1-22.

[19] Demmers, J., Fernández Jilberto, A.E. and Hogenboom, B. (2004) Good Governance and Democracy in a World of Neoliberal Regimes. In: Demmers, J., Fernández Jilberto, A.E. and Hogenboom, B., Eds., Good Governance in the Era of Global Neo-Liberalism: Conflict and Depolitization in Latin America, Eastern Europe, Asia and Africa, Routledge, London, 1-32.

[20] Brautigam, D. (2000) Aid Dependence and Governance, Expert Group on Development Issues (EGDI) Research Paper, Issue No. 1.

[21] Haji, I. (2013) Foreign Aid and Its Effect on Democratization in Post-1991 Ethiopia. Interview Held in Addis Ababa, Ethiopia.

[22] Furtado, X. and Smith, J. (2007) Ethiopia: Aid, Ownership, and Sovereignty. Managing Aid Dependency Project, Global Economic Governance (GEG) Working Paper No. 28.

[23] Awetu, S. (2013) Foreign Aid and Its Effect on Democratization in Post-1991 Ethiopia. Interview Held in Addis Ababa, Ethiopia.

[24] DAG-Ethiopia (2010) A Profile of Development Partners in Ethiopia: Official Development Assistance. http://www.dagethiopia.org/ dagethio/index.php?option=com docman\&amp;task=cat view\&amp;Itemid=120

[25] Dessalegn, R. and Ayenew, M. (2004) Democracy Assistance to Post-Conflict Ethiopia: Building Local Institutions? Democratic Transition in Post-Conflict Societies Project, Working Paper 27.

[26] Adugan, L. (2007) Anatomy of Foreign Aid to Ethiopia: 1960-2003. Working Paper, Economics Faculty Publication Series, University of Massachusetts, Boston.

[27] Human Rights Watch (2010) Development without Freedom: How Aid Underwrites Repression in Ethiopia. http://www.hrw.org/sites/default/files/reports/ethiopia1010webwcover.pdf

[28] Yissma J. (2013) Foreign Aid and Its Effect on Democratization in Post-1991 Ethiopia. Interview Held in Addis Ababa, Ethiopia.

[29] Berhanu A. (2013) Foreign Aid and Its Effect on Democratization in Post-1991 Ethiopia. Interview Held in Addis Ababa, Ethiopia. 
[30] Mushe S. (2013) Foreign Aid and Its Effect on Democratization in Post-1991 Ethiopia. Interview Held in Addis Ababa, Ethiopia.

[31] Merera G. (2013) Foreign Aid and Its Effect on Democratization in Post-1991 Ethiopia. Interview Held in Addis Ababa, Ethiopia.

[32] Meyer, C. (2012) Aiding Development or Aiding Politics? How Politics in Sub-Saharan Africa Impact the Efficacy of Official Development Assistance in Ethiopia. The Journal of Sustainable Development, 9, 47-69.

[33] Wondimagegn D. (2013) Foreign Aid and Its Effect on Democratization in Post-1991 Ethiopia. Interview Held in Addis Ababa, Ethiopia.

[34] Brown, S. (2005) Foreign Aid and Democracy Promotion: Lessons from Africa. The European Journal of Development Research, 17, 179-198. http://dx.doi.org/10.1080/09578810500130799

[35] Development Assistance Group-Ethiopia. http://dagethiopia.org/index.php?option=com_content\&view=category\&layout=blog\&id=80\&Itemid=122

[36] DIP (2011) Democratic Institutions Program Annual Report. http://www.undp.org/.../DIP\%202011 \%20 Annual\%20 Report\%20final.pdf

[37] UNDP (the United Nations Development Program) Official Website. http://www.et.undp.org/index.php?Itemid=131\&f=2\&option= com_focuslist

[38] Democratic Institutions Program Annual Report (2010). http://www.google.com.et/url?sa=t\&rct=j\&q=\&esrc=s\&source=web\&cd=1\&ved=0CCoQFjAA\&url=http\%3A\%2F\%2 Fwww.dagethiopia.org\%2Findex.php\%3Foption\%3Dcom_docman\%26task\%3Ddoc_download\%26gid\%3D161\%26It eid\%3D120\&ei=wvqMUdK3D4Ta4QTf_oDABg\&usg=AFQjCNGxbCTdfOzbC325CGLJ1bF6piY1wQ\&bvm=bv.463 40616,d.bGE\&cad=rja

[39] UNDP (The United Nations Development Program) (2006) Country Evaluation, Ethiopia: Assessment of Development Results.

http://www.google.com.et/url?sa=t\&rct=j\&q=\&esrc=s\&source=web\&cd=\&cad=rja\&ved=0CDIQFjAA\&url=http\%3A\%2 F\%2Fwww.undp.org\%2Fevaluation\%2Fdocuments\%2FADR\%2FADR_Reports\%2FADR_Ethiopia.pdf\&ei=oD2WUan GFYjcsgb5tIHACQ\&usg=AFQjCNFUPc4sqI9s7RMKrW-eYxjHJM7kBA\&bvm=bv.46751780,d.Yms

[40] Hussein, J. (2001) The Debate over Rural Land Tenure Policy Options in Ethiopia: Review of the Post-1991 Contending Views. Ethiopian Journal of Development Research, 23, 35-84.

[41] Dessalegn, R. (2002) Civil Society Organizations in Ethiopia. In: Zewde, B. and Pausewang, S., Eds., Ethiopia: The Challenge of Democracy from Below, Elanders Gotab, Stockholm, 103-119.

[42] Center for Democracy and Governance (1999) Report: USAID Political Party Development Assistance. USAID, Washington DC.

[43] Center for International Human Rights (2009) Report: Sounding the Horn: Ethiopia’s Civil Society Law Threatens Human Rights Defenders. School of Law, Northwestern University, Chicago.

[44] House of Peoples' Representatives of Ethiopia (2009) The Charities and Societies Proclamation, Addis Ababa, Ethiopia.

[45] Jubilee Campaign Report (2009) United Nations Human Rights Council Universal Periodic Review: Ethiopia.

[46] Amnesty International (2009) Ethiopian Parliament Adopts Repressive New NGOs Law. http://www.unhcr.org/refworld/docid/49670bb914.html

[47] Pausewang, S., Tronvoll, K. and Aalen, L., Eds. (2002) Ethiopia Since the Derg: A Decade of Democratic Pretension and Performance. Zed Books, London. 